\title{
Federalism in Germany, Italy, and the European Union: History, Characteristics, and Perspectives
}

\author{
Beate Jochimsen*
}

Berlin School of Economics and Law (HWR), German Institute for Economic Research (DIW), Berlin, Germany

Received January 30 2018; Accepted February 182018

\begin{abstract}
Federalism is always torn between the principles of subsidiarity and solidarity. Defining the federal structure of a country by finding the welfare-maximizing amount and design of government layers is challenging. Thereby, the financial endowment of different layers of government which they need to fulfill their respective tasks is an important aspect. European countries have chosen quite different federal designs to address the question of an optimal degree of fiscal decentralization. The aim of this paper is to analyze these different approaches for Germany, Italy, and the European Union. Parallels can be found in that all the three entities share a form of institutional asymmetry, a kind of fiscal bailout system, and a sort of fiscal equalization scheme.
\end{abstract}

Keywords: Federalism $\bullet$ Germany $・$ Italy $・$ Europe

JEL-Classification: $H 77 \bullet P 51 ・ 052 ・ N 43$

\section{Introduction}

Identifying the sources of individual well-being has been a major challenge in social sciences for many years. To what extent federal institutions support life satisfaction is an interesting aspect in this discussion. Frey and Stutzer (2000) found that individual happiness increases with the degree of decentralization, i.e., with the extent of federalism. The question then is what is the ideal degree of federalism for people's happiness? Finding the welfare-maximizing amount of government layers and allocating tasks to these different layers are challenges that have already been addressed by many politicians and academic scholars (Brennan and Buchanan 1980; Wildasin 1997; Goodspeed 2002). One major part of federal structures is the financial endowment of different layers of government which they need to fulfill their respective tasks. This aspect of federalism is usually called fiscal federalism.
European countries have chosen quite different federal designs to address the question of an optimal degree of fiscal decentralization. Germany, Italy, and the European Union (EU), for example, are all structured more or less in a federal, i.e., decentral, way. They therefore face several similar challenges although they still vary in many aspects. Parallels can be found in that all three entities share a form of institutional asymmetry, a kind of fiscal bailout system, and a sort of fiscal equalization scheme.

The aim of this paper is to analyze different approaches to federalism in Germany, Italy, and the EU giving special attention to fiscal federalism. It is organized as follows: after this introduction, various aspects of the history of federalism, mainly within Germany, Italy, and the EU, are provided in Section 2. In Section 3, following a short theoretical overview, three characteristics of modern fiscal federalism are discussed for the three entities. Finally, perspectives for further developments 
in (fiscal) federalism in Germany, Italy, and the EU are offered in Section 4.

\section{History of federalism}

\subsection{Federalism and its roots}

The ancient Greeks can be seen as the "inventors" of federalism. Their civilization was characterized by small and large alliances, partly organized like today's federal states. The core question of each Greek alliance was quite similar to that of modern scholars of federalism, namely what degree of autonomy should members get? Put differently, to what extent should they be allowed to pass own laws or raise revenue? Astonishingly, the term "federalism" has its root in the Latin word foedus, meaning "treaty, pact, or covenant" although the Roman Empire was organized centrally. Renownedly, all roads lead to Rome (Funk 2010, p.27).

Some people argue that elements of political federalism can be found in Christianity, too. They refer to the structure of the early Christian Church as described in the New Testament. Federal elements might be seen, for example, in the Council of Jerusalem, described in Acts of the Apostles, chapter 15, where the Apostles and elders meet to discuss the rules for the Christian Church; the Apostles being representatives of the universal Christian Church, i.e., the central level, and elders being representatives for local churches corresponding to the local level. To this day, elements of federalism can be found in almost every Christian denomination. Corresponding to federal states, the Christian Church, particularly the protestant, is based on several layers of "governments," i.e., vertical organizational entities.

\subsection{History of federalism in Germany}

Germany had been organized under the federal mode of government for $>1000$ years with no concrete starting point. In medieval times, princes and dukes of German regions regularly elected a king from its midst. This was a major root of federalism, because it prevented a single noble family from gaining concentrated power and territory among their members. The Golden Bull of 1356 can be taken as a first constitution regulating - among others - the election of the king who, by then, was the emperor of the Holy Roman Empire of the German nation. Therefore, voting rights were split between four secular and three spiritual princes coming from various regions of the empire (Funk 2010, pp.3536 ). One consequence of the Golden Bull were the regular meetings of the regional princes, called the Imperial
Diet (Reichstag). In 1495, the Diet of Worms agreed on the first central tax, the so-called Gemeiner Pfennig, which had to be paid by each inhabitant above the age of 15 years. Thus, the Gemeiner Pfennig only survived 60 years before the Imperial Diet abolished it and turned back to contributions by regions and cities to the central level according to their ability to pay measured in inhabitants (Matrikularbeiträge). In contrast to the central tax where the Imperial Diet had a fixed tax base and tax rate for the entire taxable territory, how they raised these contributions in their territory was left up to the regions. Consequently, many princes and dukes took the opportunity and introduced regional surcharges when they collected the central contributions from their subjects (Funk 2010, pp.81-91). Taking into account early modern times' standard, including a weak tax administration, tax moral was quite high. Up to $90 \%$ of assessed taxes could be collected. When the Turks were underway to attack the Reich, the taxpayers' willingness to pay was particularly high (Funk 2010, p.92). These contributions remained in place for $>500$ years and were only abandoned in 1919. Fifteenth century, therefore, can be seen as the cradle of fiscal federalism in Germany.

Similar to the Holy Roman Empire, which ended in 1815, the German Confederation (1815-1866) had always been designated to balance two different aims of territorial government, namely the preservation of the autonomy of local units and intra-institutional power sharing through federal institutions. In addition, indeed, traces of this distribution of power were carried over from those earlier arrangements into the constitution of the (second) German Empire in 1871. On the one hand, Article 4 of the constitution gave legislative powers over a wide range of subjects to the federal Reichstag, whereas the constitution did not specify competences of the states. Furthermore, Article 2 established the superiority of federal over state law. Both provisions can be seen as an indispensable concession that Bismarck had to make to the strong unitarian ambitions of the liberal national movement and, partly, the social democrats. These political movements were advocating to abolish (or at least to reshape) the majority of German federated states of that era, as they were considered to be mostly monarchist remanences of the feudal structures of the Middle Ages (Funk 2010, p.236). On the other hand, the states were left with substantial autonomy in areas such as social welfare, education, and cultural policies (Broschek 2012, p.669). However, with the introduction of a nationwide social security system in the 1880 s, the states soon lost important parts of their autonomy in the field of social welfare.

In contrast to modern times, the constitution of 1871 was provided for a clear division of taxing powers between the central level (Reich) and the states. 
According to Article 70 of the constitution, the federal level only had access to tariffs, revenue from postal services, and excise duties such as taxes on beer, tobacco, coffee, tea, salt, or sugar, whereas the states had exclusive jurisdiction over direct taxes on income and property. Still, the states had to continue to support the financial needs of the central government with their Matrikularbeiträge based on the number of inhabitants. To overcome the dependency of the Reich on the states' contributions, German chancellor Otto von Bismarck heavily raised tariffs - with overall negative consequences for the economy (Funk 2010, pp.239-241).

The allocation of competences between the two layers of government in combination with states' participation in federal legislation via the Bundesrat (upper chamber) appeared as defining features of Germany's federal system. A great number of well-developed subnational institutions provided one key building block of federalism, particularly because the federal level had no sufficient bureaucratic infrastructures. State building on the level of constituent units had already begun after 1648 (Westfälischer Frieden) when states increasingly became involved in the international system as selfdetermining actors. When the German Confederation was created in 1815, many German states were at the peak of their power, most of them maintaining control through an extensive bureaucracy and a standing army (Green 2003). Even after 1871, the lack of modern bureaucratic capacities at the federal level prevented it from adequately implementing legislation without the support of the states (Broschek 2012, p.670).

This federal arrangement came to a preliminary end with the Constitution of Weimar and the fiscal reforms of Matthias Erzberger in 1919 which led to a complete centralization of fiscal power. By then, the Reich had exclusive legislation on tariffs and excise duties and could claim legislation on all other taxes. With the complete loss of tax-setting autonomy, the states now heavily depended on the Reich sharing her tax revenues with them. Instead of paying Matrikularbeiträge to the central government, the situation had completely turned around and by then the states furthermore had to rely on vertical transfers from the Reich. This was the beginning of a fiscal equalization system (Funk 2010, p.265). The centralized structure remained in place during Nazism (1933-1945). Hitler viewed federalism as an obstacle to his aims, writing in Mein Kampf, "National Socialism must claim the right to impose its principles on the whole German nation, without regard to what were hitherto the confines of federal states" (Hitler 1924/2015, p.424).

Whereas the centralization of (fiscal) institutions stayed in place in East Germany (German Democratic Republic) until 1990, the basic law (Grundgesetz) in West Germany relaunched federalism in 1949. The founders of the Federal Republic of Germany coming from both central and regional government layers reestablished the federal system based on its roots in the (second) German Empire of 1871.

The federal government reoccupied a large part of legislation formally falling under concurrent legislation including predominance of the federal level over concurrent legislation. State governments often voluntarily agreed to transfer legislation to the federal level in exchange for a more extensive role in the federal legislation process through the Bundesrat. Two constitutional reforms in 1955 and 1969 further intensified this development. The separate structure of tax powers was replaced by a system of joint taxation. In addition, horizontal and vertical fiscal equalization significantly expanded, and the so-called joint tasks were introduced. The latter made tasks formally exclusively in the legislative power of the states subject to joint planning and cost sharing. In many areas, remaining elements of cooperative federalism were gradually transformed into arrangements of joint decisionmaking (Broschek 2012, p.677). Consequently, the federal level and the states increasingly found themselves in a joint decision trap, because many decisions had to be agreed upon by the central level as well as by the regions.

Since German unification in 1990, several reforms of federalism have taken place. Cautious attempts to disentangle joint decision-making, e.g., abolishment of many joint tasks, state-specific payment of civil servants, and a very small tax legislative competence for the states, strengthened the states' autonomy slightly. In view of the increased legislative powers of the states' parliament, the reforms can be regarded as a step toward decentralization (Benz 2008, p.451).

Nowadays, federal structures, mainly the German states, are widely not only accepted but also appreciated by the German population. Although there are ongoing debates as to whether, for example, education politics should be centralized, the existence of the states is continuously legitimized by state election participation rates of $60-70 \%$. Furthermore, most citizens are more satisfied with their regional politicians than with the national ones (Funk 2010, p.19).

\subsection{History of federalism in Italy}

Unlike in Germany, Italian federalism did not originate from an aggregation of separate states but from the internal reform of one preexisting unitary state in the 19th century. Germany and Italy's "founding fathers and mothers" faced two very different preunification patterns of institutional development. In Germany, strong subnational institutions provided the core of federalism. 
In Italy, these institutions' absence detained federalism. This crucial difference in the organization of local power continues to shape debates about federalism in Italy and Germany currently.

Still, federal ideas have a long history in Italy, having been discussed at the time of unification, during the late 19th century, after the First World War and again after the fall of fascism. Although regional governments were planned in the 1948 constitution, initially only five "special status" regions were set up. Regions with an ordinary status only followed in 1970 and gained their competences even later in the decade, still on a lower level than originally foreseen. Lacking fiscal capacity or real legislative autonomy caused a failure of civil society and policy communities to reorganize at the regional level (Keating and Wilson 2010, p.3).

One problem occurred due to the tight fiscal situation of the regions. Local and regional governments lost most of their remaining tax powers in the 1970s and became even more dependent on central transfers. As a consequence, there was no incentive for fiscal discipline and the central level regularly bailed out governments that ran out of funds. In the late 1990s, as Italy sought to qualify for the Euro, and continuing into the 2000s, the central state had pursued more effective mechanisms for fiscal control and responsibility. Another reason was that it had faced increasing complaints from donor regions about the transfers to the south and the apparently wastefulness of the projects they financed (Keating and Wilson 2010, p.4).

In 2009, the Italian parliament passed a law that profoundly reshaped fiscal relationships between central, regional, provincial, and municipal governments aiming at increasing both the efficiency and accountability of subnational governments and at guaranteeing suitable levels of subnational public services across the country (Blöchliger and Vammalle 2012, p.95).

Like in Germany, nowadays, there is broad public support for federalism, i.e., regional autonomy, however, with some territorial differentiation. Italians from the north favor greater regional autonomy even more than southern Italians. The latter are generally less trustful of their local and regional institutions compared to those of the central state (Keating and Wilson 2010, p.4-5).

\subsection{History of federalism in the EU}

European integration up to the founding of the EU originated in the awful experiences of the Second World War when Europe consisted of sovereign nation states without any (functioning) inter- or supranational institutions. Although the EU is not called a federation, it contains various federal elements. There are, for example (at least), two levels of government: the central, i.e., European, one and the regional one, i.e., the nation state. These two levels have been struggling for competences ever since the first steps toward European integration were taken. Furthermore, the lower level, i.e., the nation state, is in many regards autonomous. Thus with further European integration - the nation state has lost more and more competences to the European level, e.g., in economic policy. However, with regard to budgetary competences and fiscal affairs, nation states have hardly transferred competences to the European level. Although there has been an ongoing discussion for decades, the EU still has no tax-setting competences, i.e., there is no European tax. More recently, particularly after the European debt crisis in 2010, there have been discussions on issuing European bonds to pool the national risks of bond default. However, to date neither European bonds exist nor the EU has the competence to finance its own budget via debt.

Within the EU, several states are regarded as being federal, such as Austria, Germany, or Belgium. Italy is not usually mentioned as a federal country.

Germany and the EU have some federal characteristics in common:

1. Both have a bicameral legislature with a lower house (Deutscher Bundestag (German Parliament) and the European Parliament) and an upper house (the German Bundesrat (Federal Council) and the Council of the EU).

2. Members of the federal upper houses are neither elected nor appointed. Instead, they comprise members or delegates of the governments of their constituents. ${ }^{1}$

3. Different constituents represented in the "upper house" do not have the same number of votes, contrary to the widespread federal principle that one of the two houses of parliament has to grant equal voting power to the unequally sized and populated federated entities (e.g., the US Senate).

\section{Characteristics of modern fiscal federalism}

\subsection{Theoretical background of fiscal federalism}

Fiscal federalism can be seen as a permanent struggle between subsidiarity and solidarity. Both principles are

1 The USA had a similar system until 1913, where prior to the 17th amendment, senators were delegates of the state elected by the state legislatures rather than the citizens. 
rather old and have interdisciplinary roots. The former in particular has its foundation in Catholic social doctrine, where it is "the primary orienting principle for determining the proper allocation of responsibility and authority among various entities in a given society" (Golemboski 2015, p.527). Put differently, who is responsible for what in society? Subsidiarity proposes that hierarchically lower entities are usually better qualified to address individual needs and should therefore be given priority in doing so. Basically, tasks that can be fulfilled by smaller bodies ought not to be preoccupied by larger or higher ones (Golemboski 2015, p.528).

Nowadays, many authors claim an affinity between subsidiarity and constitutional or fiscal federalism (Calabresi and Bickford 2014), where subsidiarity is generally seen as a support of decentralization and federalist political arrangements. Whenever individuals or local governments can deal effectively with their problems, they should do so. However, if they cannot, because some tasks exceed their abilities, these tasks should be handled by a higher level of government. Thus, in a strict sense, subsidiarity can also provide an argument for centralization.

Some scholars see a core difference between (fiscal) federalism and subsidiarity, because the former defines the distribution of authority among political units, whereas the latter concerns the proper arrangement of powers and responsibilities among a much wider range of social entities, for example, individuals or families. Furthermore, within subsidiarity, these entities possess their own authority regardless of their ability to handle their tasks adequately, whereas in fiscal federalism various entities are pure instruments to enhance individuals' utility. Both of these views might result in the devolution of authority in many aspects (Golemboski 2015, p.540).

After having extracted the theoretical differences and similarities between subsidiarity from a Catholic perspective and from a constitutional or fiscal federal one, this paper continues to use the term "subsidiarity" in an economic sense. Two major economists who pioneered in the field of fiscal federalism are William Oates and Charles Tiebout. Oates explained that it will always be more efficient for local than for central governments to provide an efficient level of a public good, as long as the central government is incapable of discriminating public policy on a regional or local basis due to information asymmetries. This is called the decentralization theorem (Oates 1972). Tiebout transferred the ideas of competition and choice into the public sphere, precisely into the provision of public goods. If different municipalities provided different baskets of public goods at different prices, i.e., tax rates, individuals would move to the municipality which maximizes their utility. Thereby, individuals would "vote with their feet" according to individual preferences, and this behavior would result in an equilibrium provision of local public goods according to different tastes (Tiebout 1956). Thus, as preferences might vary parallel to income, rich and poor municipalities might emerge making the redistribution of income within municipalities rather difficult. Consequently, this kind of competition raised the argument that distributive tasks - emerging from the idea of solidarity - can be better carried out at a central level. Furthermore, Tiebout neglected regional spillovers leading to a suboptimal level of wealth. The centralization of tasks internalizes local or regional spillovers and, as a consequence, enhances national wealth. Another argument for centralization might be the existence of economies of scale, i.e., cost advantages for the central level in providing certain public goods (Jochimsen 2008, p.541).

Being torn between subsidiarity and solidarity or centralization and decentralization, modern federalism in Germany, Italy, and the EU is shaped by at least three common characteristics: institutional asymmetry, challenging debt rules and bailouts of regions as well as sophisticated fiscal equalization systems.

\subsection{Institutional asymmetry}

According to the principle of institutional symmetry to reach optimal results, the taxpayer, decision-maker, and beneficiary should be identical (Wicksell 1896). If beneficiaries decide upon the amount of public goods and payment modalities, the number of free riders receiving those goods without paying for them is minimized. In Germany, Italy, and the EU, by contrast, institutional asymmetry is exemplified to different degrees. In "Germany," there is not only joint decisionmaking between different layers of government but also joint revenue-raising and revenue sharing. Within the fiscal relationships between the national and the regional level (Bund and Länder), every actor faces an incentive to let someone else pay their bill while at the same time there are very few incentives for regions for own effort, e.g., to collect taxes properly (Jochimsen 2008, p.542).

Institutional asymmetry in Germany is briefly illustrated with an example: many welfare laws have to pass the national parliament (Bundestag) and the upper chamber (Bundesrat). Consequently, the legislative design of social welfare tasks and expenditures is a result of joint decision-making between the two upper levels of government. Thus, many social welfare expenditures are paid by the local level based on the number of locally entitled persons but following given national laws. Finally, these social welfare expenditures have 
to be financed. Overall, revenue mainly relies on joint taxes, where tax revenue is shared between the Bund, the Länder (regions), and sometimes the Gemeinden (local level). In 2016, around $72 \%$ of overall tax revenue came from joint taxes. Whereas the federal level has no restrictions concerning the design of their own taxes, subnational governments have hardly any taxsetting power. The regions, for example, have no taxsetting power. ${ }^{2}$ Still, by voting in the Bundesrat (upper chamber), the regions participate considerably in the tax legislation process including the distribution of joint taxes. Consequently, citizens have no idea which government level is responsible for their tax burden nor who is responsible for welfare spending. Both make it almost impossible for them to control their governments (Jochimsen 2008, p.542).

With the endorsement of Law 42 on fiscal federalism in 2009, the Italian parliament paved the way toward fiscal federalism and decentralization in "Italy." Tax and spending autonomy of the regions was increased; the fiscal equalization system was overhauled. The former secured the support of the wealthier regions in the north, the latter that of Italy's southern regions. Parallel, in the Domestic Stability Pact (DSP), the central government imposed stricter fiscal rules while allowing the regions more flexibility in implementing them (Blöchliger and Vammalle 2012, p.94). Thus, the 2009 reform touched on institutional asymmetry (was lowered), regional debt rules (were tightened), and fiscal equalization (was enlarged).

Compared to the recent reforms in fiscal federalism in Germany, the Italian reform of 2009 is a distinct step toward institutional symmetry. By now, subnational governments are entitled to set own taxes or shares in national taxes to cover their spending needs. The Italian regions receive the revenue of taxes on productive activities as well as on personal income tax and are entitled to set tax rates on these taxes within a certain range. Only the value-added tax remains a pure form of a joint tax where regions receive a part of the total national revenue. The increase in tax power for the subnational jurisdictions is fully offset by a reduction in intergovernmental grants. Furthermore, subnational governments gained autonomy on the spending side. Again, in contrast to Germany, the central government only defines minimum standards for compulsory services such as healthcare and social protection, whereas standards for all other public services can be defined at a regional or even local level (Blöchliger and Vammalle 2012, p.95).

2 There is one small exemption to this rule. The Länder might set the tax rate of the real estate transfer tax.
Finally, the EU is dominated by institutional asymmetry i.e., an almost complete separation of tax and spending autonomy. Before going into details, it is worth noticing that the principle of subsidiarity is well established in the legal structure of the EU, Article 5 of the Lisbon Treaty (Treaty on EU). This Article further stresses that "[U]nder the principle of subsidiarity, in areas which do not fall within its exclusive competence, the Union shall act only if and in so far as the objectives of the proposed action cannot be sufficiently achieved by the Member States, either at central level or at regional and local level, but can rather, by reason of the scale or effects of the proposed action, be better achieved at Union level" (TEU, Article 5(3)).

In the policy areas defined in the Lisbon Treaty, e.g., agriculture or cohesion, the European institutions, i.e., the European parliament and the European Commission, have a sort of legislative power regarding expenditure programs. Put differently, the EU has some autonomy when it comes to spending decisions. However, this is not the case when it comes to raising revenue. There is no tax-setting competence at all at the European level. The EU's fiscal bases are annual contributions by member states similar to the ancient Matrikularbeiträge of the German regions to the central level and, to a very low degree, EU tariffs. As the amount of member states' contributions depends on their respective gross national product (GDP) as well as on their respective value-added tax revenue, they are sometimes referred to as "EU taxes." This is a clear misinterpretation, because each member state is completely free to raise the required contributions however it wishes.

To sum up, one can identify institutional asymmetry in all three entities, although to different degrees. Whereas the EU is completely dominated by institutional asymmetry Italy after the 2009 reform included various elements of institutional symmetry. Germany lies between these poles.

\subsection{Regional debt rules and bailout of regions}

The design of financial relations between German regions (Länder) including institutional asymmetry between central and regional level gave rise to large public debt in recent decades (Figure 1). For $>50$ years and up to the year 2020, the German states will have and still have the competence to raise public debt without any serious restrictions.

In particular, politicians of the Länder faced strong incentives to finance public expenditures via debts, because they knew that, in the end, there would be a bailout from the federal level. Therefore, roughly $30 \%$ 


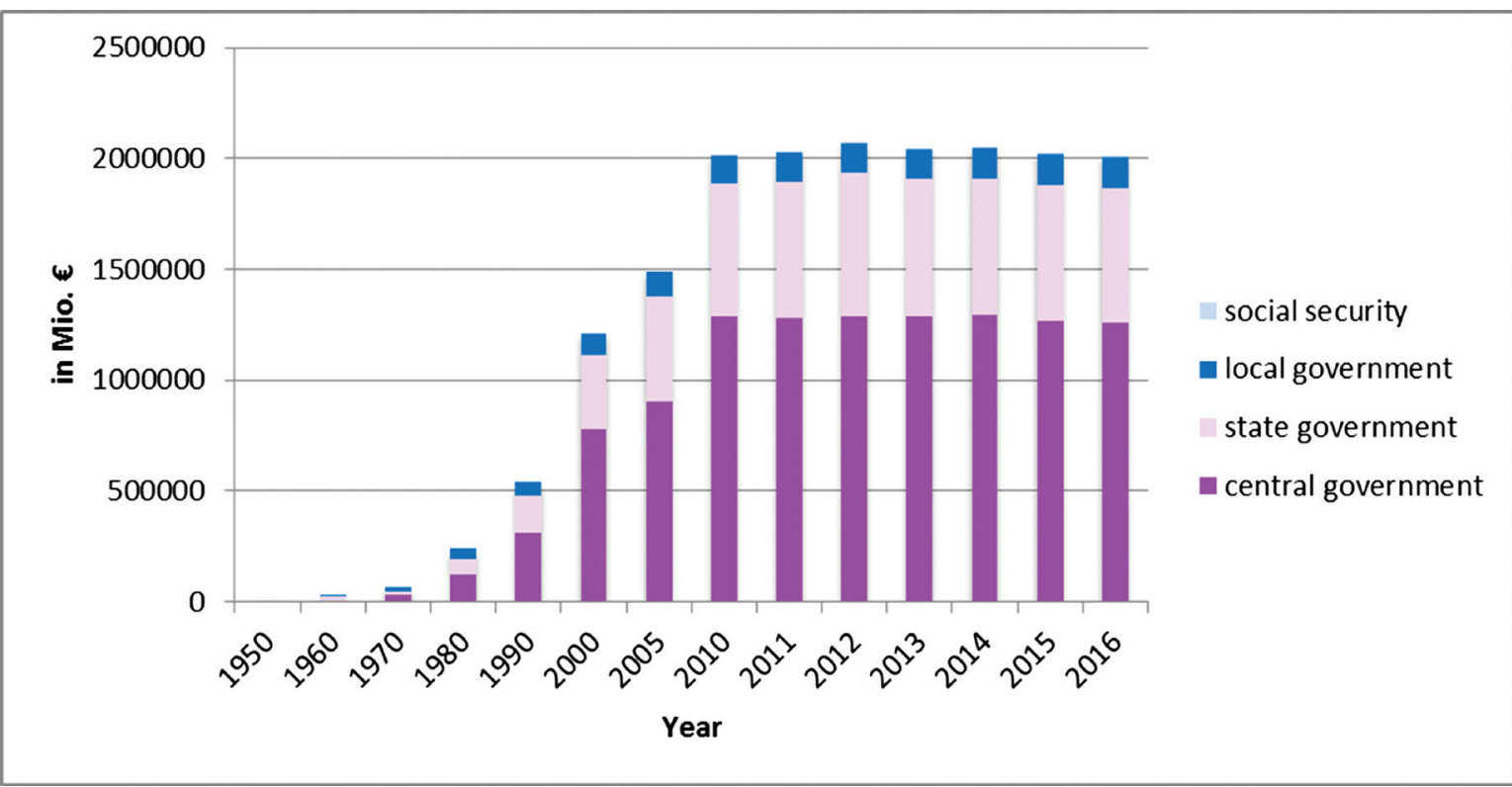

Figure 1 Development of volume and structure of public debt in Germany. Source: Statistisches Bundesamt (Federal Statistical Office) https://www.destatis.de/DE/ZahlenFakten/Gesel/schaftStaat/OeffentlicheFinanzenSteuern/OeffentlicheFinanzen/ Schulden/Tabellen/SchuldenNichtOeffentlich_Insgesamt.html.

of overall debt comes from the state level. In 1992, the constitutional court compelled the federal government to grant bailout transfers to the states Saarland and Bremen. Having accumulated very high levels of public debt, they were no longer able to provide a basic level of public services to their inhabitants (Baskaran 2012, p.1). Twenty-four years later, Berlin failed to obtain a federal bailout. Still, in this most recent judgment on federal bailouts, the federal constitutional court argued that the general bailout rule remains in place. Put differently, if worse comes to worst, the citizens of Berlin are also citizens of the Federal Republic of Germany and, therefore, will receive financial support from the national government (Bundesverfassungsgericht 2006).

From 2020 onward, new regulations on central and regional debt will be implemented. The so-called debt brake heavily restricts debt issue on both government layers; in fact, it forbids regions to raise debt in economically normal times. Nevertheless, the possibility of a bailout by the federal government still remains in place.

Up to the 1990s, regions and local governments in Italy were mainly financed by vertical transfers from the national level based on an ex post accounting of their expenditures. Consequently, there was no incentive for them to promote fiscal efficiency. On the contrary, this rule triggered a system of expansionary budgetary policy that was one of the reasons for an increasing size of public debt. Central governments were regularly forced to bail out local and regional administrations, and since the late 1990s successive governments sought to introduce greater responsibility to the subnational governments and made them raise more of their own revenue (Keating and Wilson 2010, p.11). The Maastricht criteria of 1992 and Italy's chance to join the European Monetary Union caused a change of thinking and led to the abovementioned constitutional reforms including the Domestic Stability Pact (DSP). Whereas the constitutional reform of 2001 (Article 119) already restricted local governments from borrowing to finance investment projects (Lanzilotta 2007, p.10) within DSP, raising public debt for local governments was even more restricted. For local governments, there is a limit to the debt level, originally equal to a maximum of $15 \%$ of the current revenue (Giuriato and Gastaldi 2009, p.23). Recently, this limit decreased to $8 \%$ from 2012 to 2014 and rose again to $10 \%$ in 2015 (Giannotti 2016). In case a local jurisdiction records a ratio between debt and current revenue (excluding central and regional transfers) above the limit, the allowable ratio is reduced by a percentage point. Those local governments that do not fulfill the rules of the DSP are subject to a number of sanctions, most of which require changing spending behavior. Furthermore, a "rewarding mechanism" for well-behaving local governments was introduced (Giuriato and Gastaldi 2009, p.23). Neither positive incentives nor automatic negative sanctions are part of the German debt brake, leaving it far less powerful than the DSP as long as the latter is fully accomplished.

Looking at the debt structure in Italy, one can see that net borrowing in Italy is heavily dominated by the 
central government. Nowadays, regional bailouts like in Germany are not such a serious problem (Giuriato and Gastaldi 2009, p.18).

With the European Economic and Monetary Union, both Germany and Italy face restrictions of indebtedness going beyond the rules of the European Stability and Growth Pact. However, it is in the competence of the nation states if and to what extent they integrate subnational governments in these restrictions. Still, the development so far shows that the sanctions the EU threatens when a nation state violates the European criteria are not implemented. As a consequence, national debt-to-GDP ratios have not only developed quite differently within the EU but also exceeded the Maastricht criterion of $60 \%$ for many countries and years. Following the global financial crisis in 2008/2009, a European debt crisis emerged, leading to a de facto bailout of four European countries, namely Greece, Ireland, Portugal, and Spain, by European institutions. Thus, the EU itself has no competence to issue debts.

However, not only the debt level but also the debt structure widely vary within Europe in general and between Germany and Italy in particular. Figure 2 illustrates that the central government in Germany is only responsible for less than two-thirds of overall public debt, whereas the states have risen $30 \%$ and the local level almost $10 \%$ of public debt. The situation in Italy is quite different. There, the central government is responsible for almost $95 \%$ of overall public debt and the local level for the remaining $5 \%$. Regions do not issue any public debt.

In summary, it can be said that within the nation states of Germany and Italy as well as within the EU, subcentral debt rules are in existence. Hence, the problem of public bailouts mainly exists in Germany and in other EU countries.

\subsection{Fiscal equalization system}

Within Germany, a sophisticated fiscal equalization system is based on the principal that financially strong Länder and the Bund transfer money to financially weak Länder. As aligning regions' revenue is intended to create equal living conditions for the entire population, inserting elements of competition, e.g., via the decentralization of tax power, which might lead to diverging provisions of public goods among the regions, is difficult. The central government pays additional supplementary federal grants to help extreme financially weak regions meet general financial requirements (Jochimsen 2008, p.543). In addition, East German Länder and small poor Länder receive special-need supplementary grants to compensate for different special burdens placed on them, such as structural unemployment or above-average administrative costs.

One result of this fiscal equalization system is the weak correlation between state economic performance and per capita state revenue after equalization has taken place. As a consequence, the regions have few incentives to raise their growth rate or collect more taxes. A transfer-paying land that raises one more Euro income tax is relatively richer afterward and, therefore, its payment into the fiscal equalization system increases. Depending on a number of factors, there is a great variation between how many cents are absorbed by the system and how many can be kept by the respective

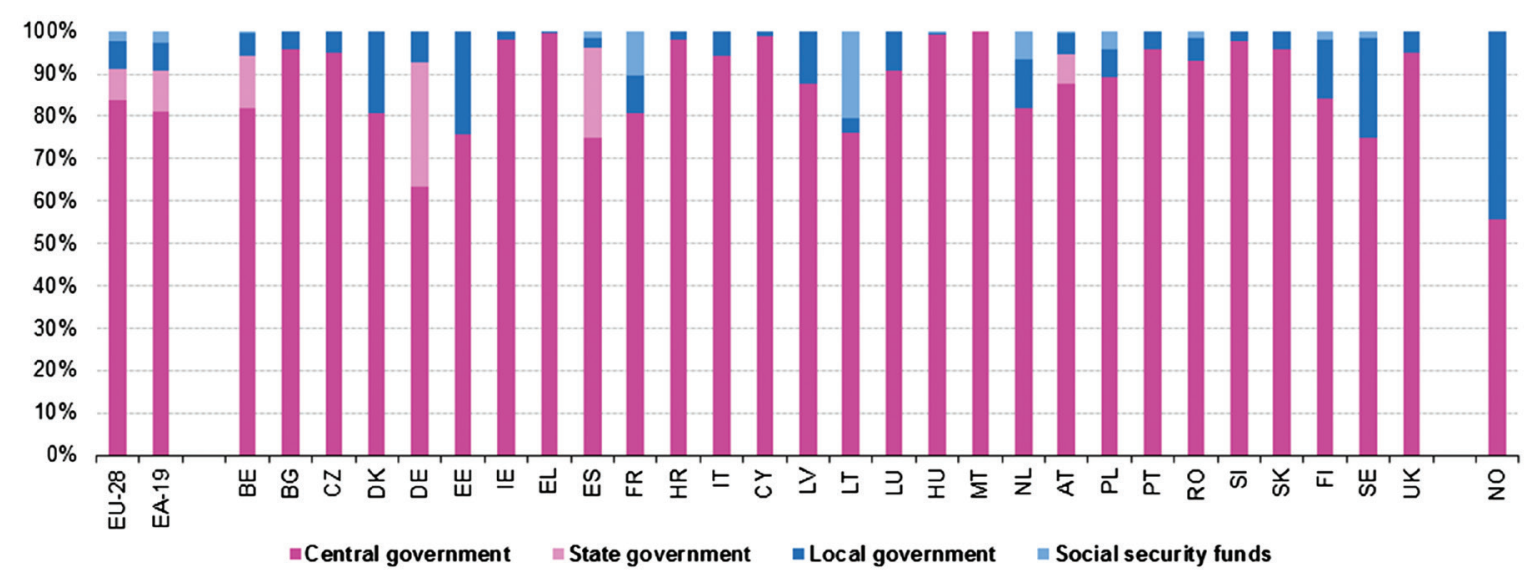

not consolidated between subsectors

Figure 2 Structure of public debt within Europe in 2016.

Source: Eurostat http://ec.europa.eu/eurostat/statistics-explained/index.php/File:General_government_gross_debt_by_subsector, percentage_of_total_gross_debt, non-consolidated_between_subsectors,_2016.png\#filelinks. 
state. For relatively rich countries, the absorption rate is roughly $80 \%$. For transfer-receiving states, it is often even higher. Raising one more Euro income tax makes them slightly richer, and transfers to them are reduced by almost 90 cents (Bönke et al. 2017). Obviously, Länder are tempted to not collect income tax (properly), because being "generous" concerning inhabitants' tax avoidance strategies might buy the incumbent government more votes than spending the remaining collected 10 cents on public goods (Jochimsen 2008, p.545).

As previously mentioned, up to the 1990s, regional and local administrative activities in Italy were not based on a system of fiscal responsibility. Instead, the regions and local governments were financed by vertical transfers from the national government on an ex post accounting of their expenditures (Lanzilotta 2007). Economic disparities remained among the highest in Europe also because there was neither a comprehensive regional policy nor a fiscal equalization system. Instead, a system of "extraordinary intervention" focused mainly on the south (Mezzogiorno) and was managed not only by the ministry of finance but also by special agencies (Cassa per il Mezzogiorno; Keating and Wilson 2010, p.3).

Part of the 2009 constitutional reforms in Italy that had already roots in the 2001 reforms was the introduction of two different fiscal equalization systems that are both funded through a share of the national value-added tax. That means that, in contrast to Germany, there are only vertical transfers from the national to regional level and no horizontal transfers between the regions. The first equalization system completely equalizes the costs for essential and compulsory services; the second equalizes tax-raising capacity but with an equalization rate below 100\% (Blöchliger and Vammalle 2012, p.95). In particular, the latter triggers similar incentive problems to the German fiscal equalization system.

In the European Treaties, an "ever closer union amongst the peoples of Europe" has been a core aim ever since. Thus, within the EU, there is no legal fiscal equalization system. However, the EU expenditure programs, particularly the structural funds, show many characteristics of such a system. European regions that are defined as being economically weak according to certain criteria (unemployment rate, GDP) are eligible for project-based transfers from the European level.

\section{References}

Baskaran T., Tax decentralization and public deficits in OECD countries, J Federalism, 42 (4), 688-707, 2012.
Noteworthy, there is - also from an economic point of view - a crucial difference between vertical transfers within nation states such as Germany and Italy: the vertical transfers from the EU to the regions are project based and have to be matched by national or regional funds, whereas the ones within Germany and Italy are unconditional and no matching grants are required.

Comparing the three equalization systems reveals another difference. Only the German system consists of vertical and horizontal transfers, the latter occur between the regions (and even between local entities within one region). The Italian and European equalization systems are only familiar with vertical transfers.

All systems also seem to have one common characteristic: in Germany and also in Italy and the EU, some regions emerged or endured that, apparently, had not managed to catch up with the economic development of the others (some parts of former East Germany, Mezzogiorno, Greece). Therefore, transfers originally intended to foster economic alignment and aiming at becoming redundant once this alignment had been reached might turn out to be permanent.

\section{Perspectives}

Currently, perspectives for federalism in Germany, Italy, and the EU are puzzling. In Germany, Bund and Länder agreed on a new fiscal equalization scheme with slightly different economic incentives starting in 2020. As mentioned earlier, a debt brake is being implemented in parallel. The consequences for the fiscal performance of the different jurisdictions are not yet clear. In Italy, the majority of the population rejected reforms on Italy's federal structure in December 2016. Therefore, the future development of federalism in Italy has not yet been settled.

Finally, in Europe, the public debt crisis starting in 2010 is not over. Although Ireland, Spain, and Portugal more or less economically and fiscally recovered, Greece is still fighting severe budgetary and debt problems. Currently, the idea of European federalism and solidarity is questioned in others ways, too, e.g., the admission and distribution of refugees. Recall that the core elements of federalism are subsidiarity and solidarity, it was and still is a challenge to find the right balance between these two principles.
Benz A., From joint decision traps to over-regulated federalism: adverse effects of a successful constitutional reform, German Polit, 17 (4), 440-456, 2008. 
Blöchliger H., Vammalle C., Italy: law 42 on fiscal federalism, In: Reforming fiscal federalism and local government: beyond the zero-sum game, OECD Publishing, Paris, 2012.

Bönke T., Jochimsen B., Schröder C., Fiscal equalization and tax enforcement, German Econ Rev, 18 (3), 377-409, 2017.

Brennan G., Buchanan J.M., The power to tax: analytical foundations of a fiscal constitution, Cambridge University Press, Cambridge, 1980.

Broschek J., Historical institutionalism and the varieties of federalism in Germany and Canada, J Federalism, 42 (4), 662-687, 2012.

Bundesverfassungsgericht, Urteil des Zweiten Senats vom 19, Oktober 2006 - 2 BvF 3/03 - Rn. (1-256), 2006.

Calabresi S.G., Bickford L.D., Federalism and subsidiarity: perspectives from U.S. constitutional law, In: Fleming J.E., Levy J.T. (Eds.), Federalism and subsidiarity, 123-189, NYU Press, New York, 2014.

Eurostat, General government gross debt by subsector, percentage of total gross debt, non-consolidated between subsectors, 2016. Available at: http:// ec.europa.eu/eurostat/statistics-explained/index. php/File:General_government_gross_debt_by_ subsector,_percentage_of_total_gross_debt, non-consolidated_between_subsectors,_2016. png\#filelinks (access Aug 21, 2018).

Frey B., Stutzer A., Happiness, economy and institutions, Econ J, 110, 918-938, 2000.

Funk A., Kleine Geschichte des Föderalismus - Vom Fürstenbund zur Bundesrepublik, Ferdinand Schöningh, 2010.

Giannotti V., I limiti di indebitamento degli enti locali nel $\checkmark$ decreto correttivo e i vincoli del pareggio di bilancio, Bilancio e Contabilità, 2016. Available at: http:// www.bilancioecontabilita.it/i-limiti-di-indebitamentodegli-enti-locali-nel-v-decreto-correttivo-e-i-vincoli-delpareggio-di-bilancio-il-commento-di-v-giannotti.html (access Aug 21, 2018).
Giuriato L., Gastaldi F., The domestic stability pact in Italy: a rule for discipline? In: MPRA Paper No 15183, Munich, 2009.

Golemboski D., Federalism and the catholic principle of subsidiarity, J Federalism, 45 (4), 526-551, 2015.

Goodspeed T.J., Bailouts in a federation, Int Tax Public Finance, 9 (4), 409-421, 2002.

Green A., The federal alternative? A new view of modern German history, Hist J, 46 (1), 187-202, 2003.

Hitler A., Mein Kampf: English edition, translated by Marco Roberto, MVR, 1924/2015.

Jochimsen B., Fiscal federalism in Germany, German Polit, 17 (4), 541-558, 2008.

Keating M., Wilson A., Reforming Italy: institutional change and the federal option, Edinburgh Europa Paper Series, 2010.

Lanzilotta L., Evolution and transformation of the Italian federalism, speech at the European Institute, London School of Economics and Political Science, March 12, 2007.

Oates W.E., Fiscal federalism, Harcourt Brace Jovanovich, New York, 1972.

Statistisches Bundesamt (Federal Statistical Office), Development of volume and structure of public debt in Germany. Available at: https://www. destatis.de/DE/ZahlenFakten/GesellschaftStaat/ OeffentlicheFinanzenSteuern/OeffentlicheFinanzen/Schulden/Tabellen/SchuldenNichtOeffentlich_ Insgesamt.html (access Aug 21, 2018).

Tiebout C., A pure theory of local expenditure, J Polit Econ, 64, 416-424, 1956.

Wicksell K., Finanztheoretische Untersuchungen nebst Darstellung und Kritik des Steuerwesens Schwedens, Jena, Gustav Fischer, 1896.

Wildasin D., Externalities and bailouts: hard and soft budget constraints in intergovernmental fiscal relations, In: World Bank policy research working paper No. 1843, 1997. 